\title{
Effect of Different in-situ Moisture Conservation Practices on Economics of Groundnut (Arachis hypogaea L.) Under Rainfed Condition
}

\author{
G. Rajitha*, G. Prabhakara Reddy, A. Muneendra Babu and P. Sudhakar \\ Department of Agronomy, Acharya N G Ranga Agricultural University, S.V. Agricultural \\ College, Tirupati 517502, A P., India \\ *Corresponding author
}

\section{A B S T R A C T}

Keywords

Conservation practices,

Economics, Groundnut, Rainfed

Article Info

Accepted:

12 July 2019

Available Online:

10 August 2019
Groundnut is the major kharif crop in alfisols of Rayalaseema region of Andhra Pradesh. Most of the groundnut crop under rainfed condition has low productivity and monetary returns. For this, an investigation was carried out during the kharif season in 2016-17 at S.V. Agricultural College, Tirupati to study the effect of in-situ moisture conservation practices on economics of rainfed groundnut (Arachis hypogaea L.). The results of the study shown that the highest monetary gains for rainfed groundnut can be attained by broad bed and furrow method of moisture conservation practice. The net returns and $\mathrm{B}$ : $\mathrm{C}$ ratio was found to be significantly higher in broad bed and furrows (₹ 35360 and 2.31) as compared to conventional tillage ( $₹ 17530$ and 1.69 respectively).

\section{Introduction}

Groundnut is called as king of oilseeds. It is one of the important food and cash crops of our country.

It is the sixth most important oilseed crop in the world. It contains $48-50 \%$ of oil and 26$28 \%$ of protein and is a rich source of dietary fiber, minerals and vitamins.

In most of the developing countries, the productivity levels of groundnut are low due to a number of production constraints such as the cultivation of the crop on marginal lands under rainfed conditions, occurence of frequent drought stress due to vagaries of monsoon, higher incidence of pests and disease attacks, low input use factors related to socio-economic infrastructure.

The moisture is the key limiting factor in the rainfed farming and rainfall is the only source of water for the vast stretch of lands. While considerable importance has been given to increase the productivity of the irrigated lands under green revolution, sufficient attention has not been given to increase the productivity of the rainfed areas resulting in low net returns and $\mathrm{B}$ : $\mathrm{C}$ ratio. 
Therefore, importance must be given to harvest maximum rain water and adopt methods to maximise the retention of moisture which increases the yield as well as monetary returns.

\section{Materials and Methods}

A field experiment was carried out during kharif, 2016-17 at S.V. Agricultural College Farm, Tirupati. The experimental soil was sandy loam in texture, neutral in reaction $(\mathrm{pH}$ $7.5)$, low in organic carbon ( 0.38 per cent) and available nitrogen $\left(149.8 \mathrm{~kg} \mathrm{ha}^{-1}\right)$, medium in available phosphorous (11.8 $\left.\mathrm{kg} \mathrm{ha}^{-1}\right)$ and available potassium (161.3 $\left.\mathrm{kg} \mathrm{ha}^{-1}\right)$. The experiment was laid out in randomised block design with eight treatments replicated thrice. The treatments comprised of Conventional tillage $\left(\mathrm{T}_{1}\right)$, vertical tillage with subsoiler upto a depth of $60 \mathrm{~cm}$ at an interval of $1.0 \mathrm{~m}$ followed by secondary tillage $\left(\mathrm{T}_{2}\right)$, deep ploughing with mouldboard plough upto a depth of $40 \mathrm{~cm}$ followed by secondary tillage $\left(\mathrm{T}_{3}\right)$, conservation furrow after every row $\left(\mathrm{T}_{4}\right)$, conservation furrow after every four rows $\left(\mathrm{T}_{5}\right)$, broad bed and furrows $(90 / 30 \mathrm{~cm})\left(\mathrm{T}_{6}\right)$, straw mulch @ 5 tonnes ha ${ }^{-1}\left(\mathrm{~T}_{7}\right)$ and soil mulch (frequent intercultivation) $\left(\mathrm{T}_{8}\right)$. Immediately after the receipt of monsoon rains, the field preparation was carried out as per the treatments.

The field was finally worked with a blade harrow for levelling and the plots were laid out according to the layout plan. The crop was sown in lines $30 \mathrm{~cm}$ apart by adopting all the standard package of practices. The entire dose of $20 \mathrm{~kg} \mathrm{~N}, 30 \mathrm{~kg} \mathrm{P}_{2} \mathrm{O}_{5}$ and $50 \mathrm{~kg} \mathrm{~K}_{2} \mathrm{O}$ was applied uniformly in all the treatments. In order to calculate the monetary returns, the amounts of inputs and cost of the input and output were specified to calculate the total cost of cultivation of groundnut in the study. Gross returns were computed by considering the prevailing market price of the output. Net returns were arrived at by deducting the cost of cultivation of respective treatments from gross returns for the corresponding treatments. Benefit-cost ratio was calculated by using the following formula.

Benefit-cost ratio $=\frac{\text { Gross Returns }\left(₹ \mathrm{ha}^{-1}\right)}{\text { Cost of cultivation }\left(₹ \mathrm{ha}^{-1}\right)}$

\section{Results and Discussion}

Gross returns, net returns and $\mathrm{B}$ : $\mathrm{C}$ ratio were statistically compared and the data are presented in Table 1.

Higher gross returns (₹ 61670) were realized with broad bed and furrow system $\left(\mathrm{T}_{6}\right)$ which was on par with vertical tillage $\left(\mathrm{T}_{2}\right)$ ( $₹$ 56150) and deep ploughing $\left(\mathrm{T}_{3}\right)$ (₹ 53720) without any significant difference between them. Straw mulch $\left(\mathrm{T}_{7}\right)$ (₹ 51350) was found to be on par with conservation furrow after every row $\left(\mathrm{T}_{4}\right)$ ( $₹$ 50720) and conservation furrow after every four rows $\left(\mathrm{T}_{5}\right)$ ( $₹$ 47870). The lowest gross returns were realized with conventional tillage $\left(\mathrm{T}_{1}\right)$ (₹ 43070).

Broad bed and furrows $\left(\mathrm{T}_{6}\right)$ resulted in highest net returns (₹ 35630) which was on par with vertical tillage $\left(\mathrm{T}_{2}\right) \quad(₹ \quad 29110)$ and significantly superior to deep ploughing $\left(\mathrm{T}_{3}\right)$ (₹ 25680), straw mulch $\left(\mathrm{T}_{7}\right)$ (₹ 20810), conservation furrow after every row $\left(\mathrm{T}_{4}\right)$ ( $₹$ 20180) and conservation furrow after every four rows $\left(\mathrm{T}_{5}\right)$ (₹ 20330). Conventional tillage $\left(\mathrm{T}_{1}\right)$ (₹ 17530) recorded the lowest net returns.

The highest benefit-cost ratio was registered with broad bed and furrows $\left(\mathrm{T}_{6}\right)$ (2.31), which was however on par with vertical tillage $\left(\mathrm{T}_{2}\right)$ (2.08) and significantly superior to deep ploughing $\left(\mathrm{T}_{3}\right)$ (1.92). The lowest benefit-cost ratio was apprehended with conventional tillage $\left(\mathrm{T}_{1}\right)$ (1.69) (Table 1). 
Table.1 Gross returns ( $\left.₹ \mathrm{ha}^{-1}\right)$, Net returns $\left(₹ \mathrm{ha}^{-1}\right)$ and B: C ratio of groundnut as influenced by different in-situ Moisture conservation practices

\begin{tabular}{|c|c|c|c|}
\hline Treatments & $\begin{array}{l}\text { Gross returns } \\
\quad\left(₹ \underline{h^{-1}}\right)\end{array}$ & $\begin{array}{l}\text { Net returns } \\
\left(₹ \underline{h a}^{-1}\right)\end{array}$ & B: C ratio \\
\hline $\mathrm{T}_{1}:$ Conventional Tillage & 43070 & 17530 & 1.69 \\
\hline $\begin{array}{l}T_{2}: \text { Vertical tillage with subsoiler upto a depth of } 60 \mathrm{~cm} \text { at an interval of } 1.0 \\
\text { m followed by secondary tillage }\end{array}$ & 56150 & 29110 & 2.08 \\
\hline $\begin{array}{l}T_{3} \text { : Deep ploughing with mouldboard plough upto a depth of } 40 \mathrm{~cm} \text { followed } \\
\text { by secondary tillage }\end{array}$ & 53720 & 25680 & 1.92 \\
\hline $\mathbf{T}_{4}$ : Conservation furrow after every row & 50720 & 20180 & 1.66 \\
\hline$T_{5}:$ Conservation furrow after every four rows & 47870 & 20330 & 1.74 \\
\hline$T_{6}:$ Broad bed and furrow $(90 / 30 \mathrm{~cm})$ & 61670 & 35630 & 2.31 \\
\hline $\mathbf{T}_{7}$ : Straw mulch @ 5 tonnes ha ${ }^{-1}$ & 51350 & 20810 & 1.68 \\
\hline $\mathbf{T}_{8}:$ Soil mulch (frequent intercultivations) & 45710 & 12670 & 1.38 \\
\hline SEm \pm & 3162 & 3162 & 0.12 \\
\hline $\mathrm{CD}(\mathrm{P}=\mathbf{0 . 0 5})$ & 9592 & 9592 & 0.36 \\
\hline
\end{tabular}


The higher gross returns, net returns and benefit cost ratio associated with broad bed and furrows $\left(\mathrm{T}_{6}\right)$ might be due to the higher pod and haulm yields. The maximum monetary yield advantage was observed with broad bed and furrows $\left(\mathrm{T}_{6}\right)$ followed by vertical tillage $\left(\mathrm{T}_{2}\right)$, deep ploughing $\left(\mathrm{T}_{3}\right)$, straw mulch $\left(\mathrm{T}_{7}\right)$, conservation furrow after every row $\left(\mathrm{T}_{4}\right)$, conservation furrow after every four rows $\left(\mathrm{T}_{5}\right)$ and soil mulch $\left(\mathrm{T}_{8}\right)$.

This might be ascribed to the best performance of the crop under comfortable moisture, resulting in better growth (Prasad, 1994).There was significant reduction in pod yields in conventional tillage as compared to broad bed and furrows due to lesser number of flowers, total pods and filled pods plant while higher yields under broad bed and furrows and vertical tillage might have been made possible by the better available soil moisture, aeration, drainage and also favourable soil physical conditions and microclimate which finally resulted in higher monetary returns. The results are in conformity with the findings of Samui and Ambore (2000) and Hulihalli and Patil (2005).
In conclusion, the investigation clearly indicate that higher pod yield of groundnut as well as economic returns could be realized with broad bed and furrows followed by vertical tillage with subsoiler.

\section{References}

Hulihalli, U.K and Patil, V.C. 2005. Effect of in-situ moisture conservation practices and organic manures on growth and yield of desi cotton (Gossypium herbaceum) under rainfed conditions. Indian Journal of Agricultural Sciences. 75(1): 55-57.

Prasad, V.N. 1994. Effect of land treatments and gypsum on growth, yield and quality of groundnut (Arachis hypogaea L.). M.Sc. (Ag.) Thesis submitted to Acharya N.G. Ranga Agricultural University, Hyderabad.

Samui, R.C., and Ambhore, S.B. 2000. Efficacy of polythene mulch technology in improving growth and yield of post rainy season groundnut in West Bengal, India. International Arachis News Letter. 20: 84-86

\section{How to cite this article:}

Rajitha, G., G. Prabhakara Reddy, A. Muneendra Babu and Sudhakar, P. 2019. Effect of Different in-situ Moisture Conservation Practices on Economics of Groundnut (Arachis hypogaea L.) Under Rainfed Condition. Int.J.Curr.Microbiol.App.Sci. 8(08): 1289-1292. doi: https://doi.org/10.20546/ijcmas.2019.808.152 